\title{
18 Temmuz 2017 Tarihinde İstanbul'da Meydana Gelen Sel Olayının Meteorolojik Analizi
}

\author{
Meteorological Analysis of Flash Flood in Istanbul on 18 July 2017
}

\author{
Hakkı BALTACI ${ }^{1}$ \\ ${ }^{1}$ Meteoroloji 1. Bölge Müdürlüğ̈̈, Bölgesel Tahmin ve Erken Uyarı Merkezi, İstanbul, Türkiye
}

$\ddot{O} \mathbf{z}$

Sel hadisenin yer yüzünde meydana gelen önemli doğal afetlerden birisi olduğu bilinmektedir. Sel nedeniyle meydana gelmesi muhtemel zararları minimize etmek için sebeplerinden birisi olan kısa süreli orta ölçekli konvektif yağışların analizi ve tahmini oldukça önemlidir. Bu çalışmada, 18 Temmuz 2017 tarihinde İstanbul'da meydana gelen sel hadisesinin meteorolojik analizi yapılmıştır. Azor Yüksek Basınç Merkezi ile İzlanda Alçak Basınç Merkezi'nin etkileşimi arasında kalan İstanbul İline, yukarı seviye alçak merkezinin bölge üzerinde konumlanması neticesinde Ege ve Marmara Denizlerinden nem transfer edilmiş̧ir. Nemin aşağı seviyelerden yukarı seviyelere kuvvetli rüzgarlar ile birlikte iletilmesi kararsılık koşullarını artırmış (K index=36.6), İstanbul İli üzerinde sabah saatlerinde kısa süreli kuvvetli yağışlara neden olmuş (Beykoz'da 1 saatte 44.0 mm yağış meydana gelmiştir) ve ekonomik ve sosyal hayatı olumsuz yönde etkilemiştir.

Anahtar Kelimeler: İstanbul, Sel, Radar, Yağış

\begin{abstract}
It is known that flash floods are one of the main natural hazards that occur on the earth. To minimize the probable risks occurring by the flash floods, analyzing and predicting of mezoscale convective systems are quite important. In this study, meteorological analysis was investigated for the Istanbul flash flood on 18 July 2017. In addition to the interaction between Azor High-Pressure Center and Island Low-Pressure Center, the position of high low center over Istanbul transferred high amount of moisture to the region by Aegean and Marmara Seas. Transferring of moisture from low to high levels by strong vertical winds increased the instability conditions $(\mathrm{K}$ index $=36.6)$ caused severe precipitation events in the morning times of the day (44.0 $\mathrm{mm}$ in one hour in Beykoz) and negatively influenced the economic and social life of the city.
\end{abstract}

Keywords: Istanbul, Flash Flood, Radar, Precipitation

\section{GİRIŞ}

En çok bilinen doğal afetlerden birisi olan seller, özellikle son yıllarda Akdeniz havzasında artan sıklıkta şiddetli taşkınlara sebep olmakta ve bir çok ülke sonuçlarıyla yüzleşmektedir [1]. Genellikle yaz ve sonbahar mevsimlerinde Akdeniz'de şiddetli yağış neticesinde görülen taşkınların başlıca sebeplerinin orta ölçekteki konvektif sistemler ile karmaşık topografya olduğu bilinmektedir. Ülkemizde de artan sıklıkta görülmeye başlayan sel ve su baskınlarının tahmininin de kolayca yapılamayışı sosyal ve ekonomik hayatı olumsuz yönde etkilemektedir. Bu nedenle, şiddetli yağışlara sebep olan atmosferik mekanizmaların arkasındaki dinamik etkenlerin araştırılması gerek tahmin ve gerekse de erken uyarı açısından oldukça önemlidir. Bu amaçla, ülkemizde meydana gelen belli başlı sel hadiselerinin meteorolojik ve hidrometeorolojik incelemeleri yapılmıştır. 3-4 Kasım 1995 tarihleri arasında İzmir'de meydana gelen sel olayı sonucunda 61 vatandaşımız hayatını kaybetmiş ve 50 milyon dolar zarar meydana gelmiştir. Sele sebebiyet veren atmosferik koşullar incelendiğinde, aşağı seviye adveksiyonu, pozitif vortisiti alanı ve güçlü yukarı seviye diverjansı başlıca nedenler olarak 
görülmektedir. Ayrıca, Ege Denizi üzerindeki alçak basınç merkeziyle beraber 11 k ve nemli kararsız havanın aşağı seviye jetleri ile Akdeniz üzerinden taşınması ve oroğrafinin de etkili olması bölgenin az zamanda çok miktarda yağış almasında neden olmuş, Ilıca ve Dallık Derelerinin taşmasına sebebiyet vermiştir [2]. 5 Aralık 2002 tarihinde Antalya'da gün içerisindeki toplam yağışın 230 mm'lere kadar ulaşması neticesinde bölgede seller meydana gelmiş, atmosferik nedeni olarak 1lık ve nemli havanın aşağ 1 seviye jetleri ile taşınması sonucu oroğrafik bariyerle karşılaşması bölgenin az zamanda çok şiddetli yağışlarla karşılaşmasına neden olmuştur [3]. Daha sonraları, 32 kişinin ölümü ile milyonlarca dolar hasar ile sonuçlanan 7-10 Eylül 2009 tarihleri arasında İstanbul'da gerçekleşen sel hadisesi meydana gelmiştir. Şehirleşmenin, yoğun nüfusun, yanlış ve kontrolsüz yapılaşmanın sonuçları şiddetli yağışlarla birleşince, sosyoekonomik hayatı felç etmiştir. Atmosferik koşullar olarak, yukarı seviyedeki soğuk hava ile birlikte yavaş hareket eden trof ve 1lık Ege Denizi üzerinden sürekli nem takviyesi konvektif hücre kümelerinin oluşmasına neden olmuştur [4]. Daha sonraları, şiddetli yağışlara sebebiyet veren gök gürültülü fırtınaların meteorolojik olarak incelemesi Esenboğa havaalanı için yapılmıştır [5]. Türkiye'de en fazla sel olayının meydana geldiği bölge olarak Doğu Karadeniz bölgesi görülmektedir. Özellikle yaz ve sonbahar mevsimlerinde kisa zamanda çok miktarda yağışların gerçekleşmesi pürüzlü topografyanın da etkisiyle selin olumsuz etkilerini artırmaktadır. En son olarak 24 ağustos 2015 tarihinde Artvin ve çevrelerinde meydana gelen sel sonucunda 11 insan hayatını kaybetmiş ve milyon dolarlık ekonomik kayıplar gerçekleşmiştir. Asya kaynaklı kopan alçak basınç merkezinin Doğu Karadeniz üzerine yerleşmesi ve bu siklonun durağan hareketi, deniz suyu sıcaklıklarının normallerinin üzerinde seyretmesi, aşağ ${ }_{1}$ seviye nem konverjans alanlarının gelişmesine neden olmuştur. Ayrıca, nemin Karadeniz üzerinden sıcak kuzeyli akışlarla transferi ile Artvin'in karasal alanlarından nispeten soğuk güneyli akışlar kararsızlık durumlarını artırmış ve derin konvektif hücrelerinin oluşmasına neden olmuştur [6].

En son olarak, 18 Temmuz 2017 tarihinde İstanbul'da sel hadisesi meydana gelmiştir (Şekil 1). Sel özellikle Gümüşyaka, Silivri ve Kınalı arasında etkili olmuş olup, ulaşımda aksamalara, ev, iş yeri ve metro hatlarına su basmaları (Şekil 2) ile sonuçlanmıştır. AKOM verilerine göre aşırı yağışla ilgili toplamda 8866 ihbar kaydı yapılmıştır. Bu çalışmada İstanbul'da en son meydana gelen sel hadisesinin meteorolojik incelemesi yapılmıştır.

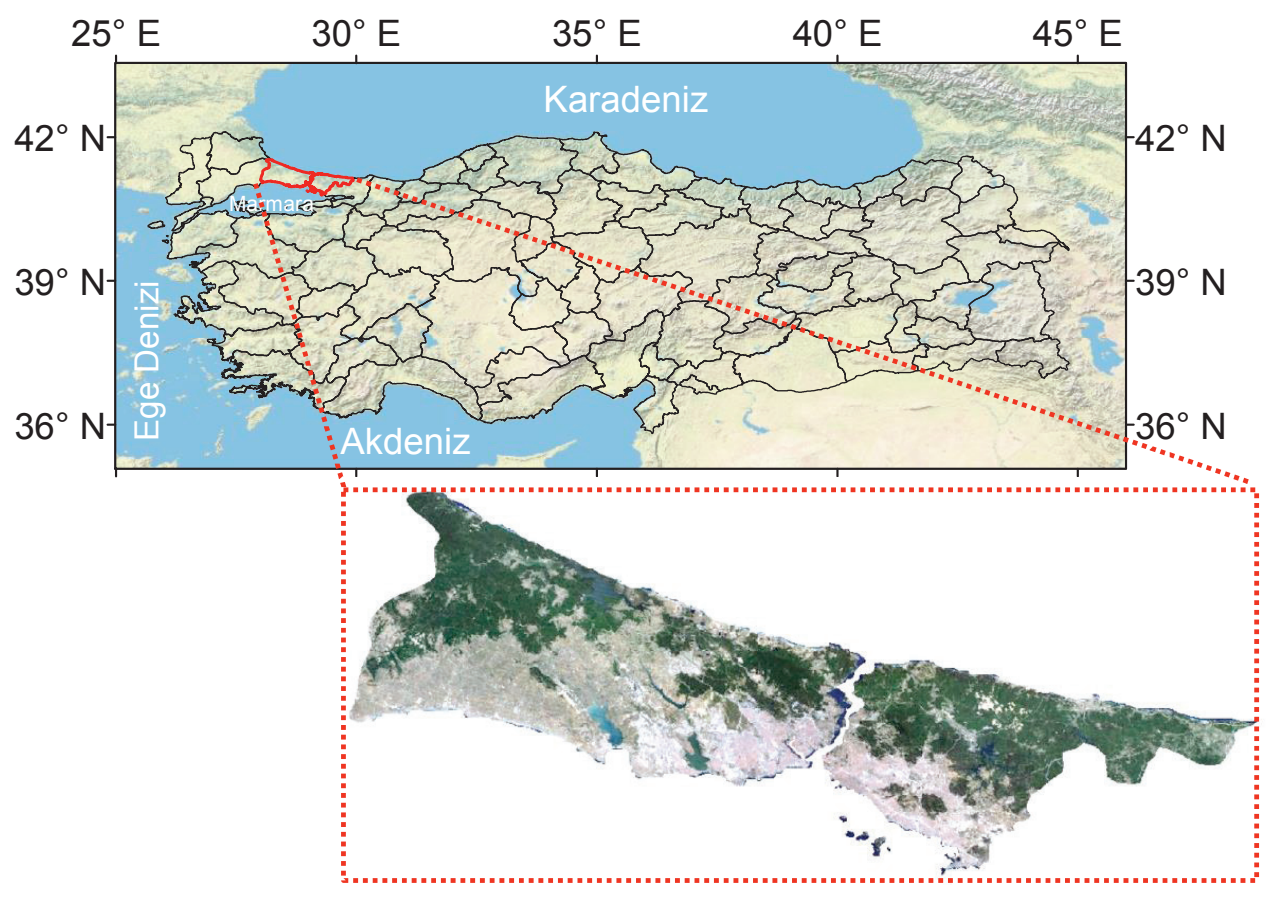

Şekil 1. Türkiye Haritası ve İstanbul İli'nin coğrafi konumu 


\section{MATERYAL VE YÖNTEM}

$\mathrm{Bu}$ çalışmada, ilk aşamada sinoptik ölçekli sirkülasyonların hareketini incelemek amaciyla yer ve yukarı seviyelerinin (500 hPa) 17 Temmuz 2017 tarihi 06:00 UTC ile 18 Temmuz 2017 06:00 UTC zamanki atmosferik haritaları incelenmiştir. Atmosferin yukarı seviyelerindeki dikine hareketi inceleyebilmek amacıyla da İstanbul Radiosonde verilerinin sel hadisesinin olduğu gündeki 00:00 UTC SkewT-logP diyagramından yararlanılmıştır. Gerçekleşen yağış miktarı ve rüzgar değerleri Meteoroloji Genel Müdürlüğünden alınan 15 istasyonun saatlik yağış ile rüzgar hız değerleri kullanılarak değerlendirilmiştir. Yağış bantlarının hareketi ve kuvvetli olduğu alanlar ise İstanbul Çatalca Radarından alınan MAX görüntüleri kullanılarak irdelenmiştir.

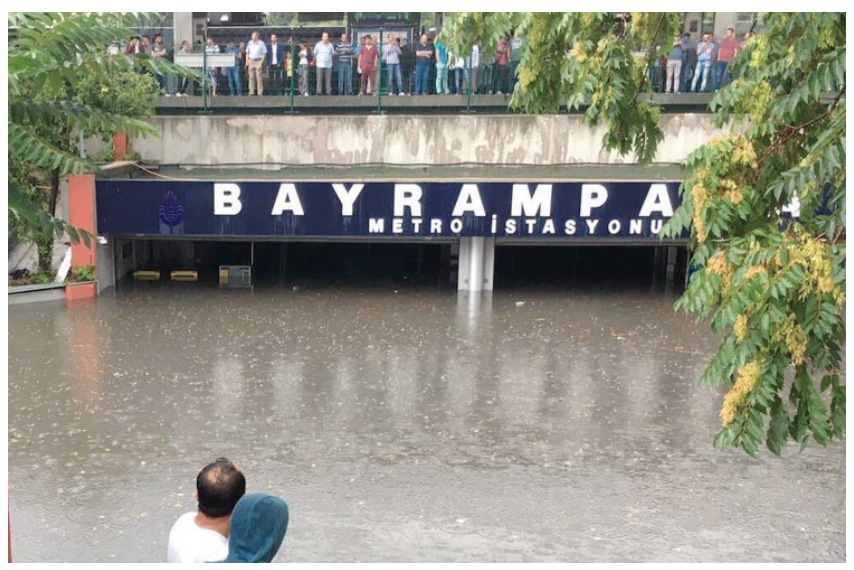

Şekil 2. 18 temmuz 2017 tarihinde meydana gelen şiddetli yağış sonucu Bayrampaşa Metro İstasyonu'nun sular altında kalması

\section{BULGULAR VE TARTIȘMA}

\subsection{Sinoptik Analiz}

Sel hadisesi meydana gelmeden 1 gün önceki sinoptik koşullar incelendiğinde, Azor Yüksek Basınç Merkezi etki alanını genişletmiş ve $1020 \mathrm{hPa}$ 'lık değeri ile Balkanlara kadar genişlemiştir (Şekil 3a). Buna ek olarak ise Türkiye'nin güney kesimlerinde etkili olan sıcak karakterli Basra alçak merkezi ise Türkiye'nin iç kesimlerine kadar uzanmıştır. İstanbul ise Azor Yüksek Basınç Merkezi ile Asya Alçak Basınç Merkezine bağlı oluğun etkisi altında olup basınç gradyanı sıkışmasından dolayı kuvvetli kuzeyli rüzgarlar Karadeniz üzerinden İstanbul'a nem taşınımını sağlamaktadır. Yukarı seviyelerde ise 568 hPa'lık alçak merkez Yunanistan üzerinde konumlanmış olup, Bölge üzerine güneyli rüzgarlar ile Akdeniz üzerinden nem transferini sağlamaktadır (Şekil 3a). Yer ve yukarı seviyeler arasındaki akışların farklılığından dolayı belirgin sıcaklık farklılıkları meydana gelmiş ancak 500$\mathrm{hPa}$ alçak merkezin İstanbul'a uzaklığından dolayı kuvvetli kararsızlık koşulları tam anlamıyla oluşmamıştır. 18 Temmuz 2017 sabah saatlerinde ise yer seviyesindeki basınç merkezlerinin konumunun değişmemesine ek olarak yukarı seviyede bulunmakta olan alçak merkez batılı hareketi neticesinde Marmara Bölgesi üzerine yerleşerek Ege ve Marmara Denizleri'nden kuvvetli nem transferi gerçekleşmiştir (Şekil 3b).
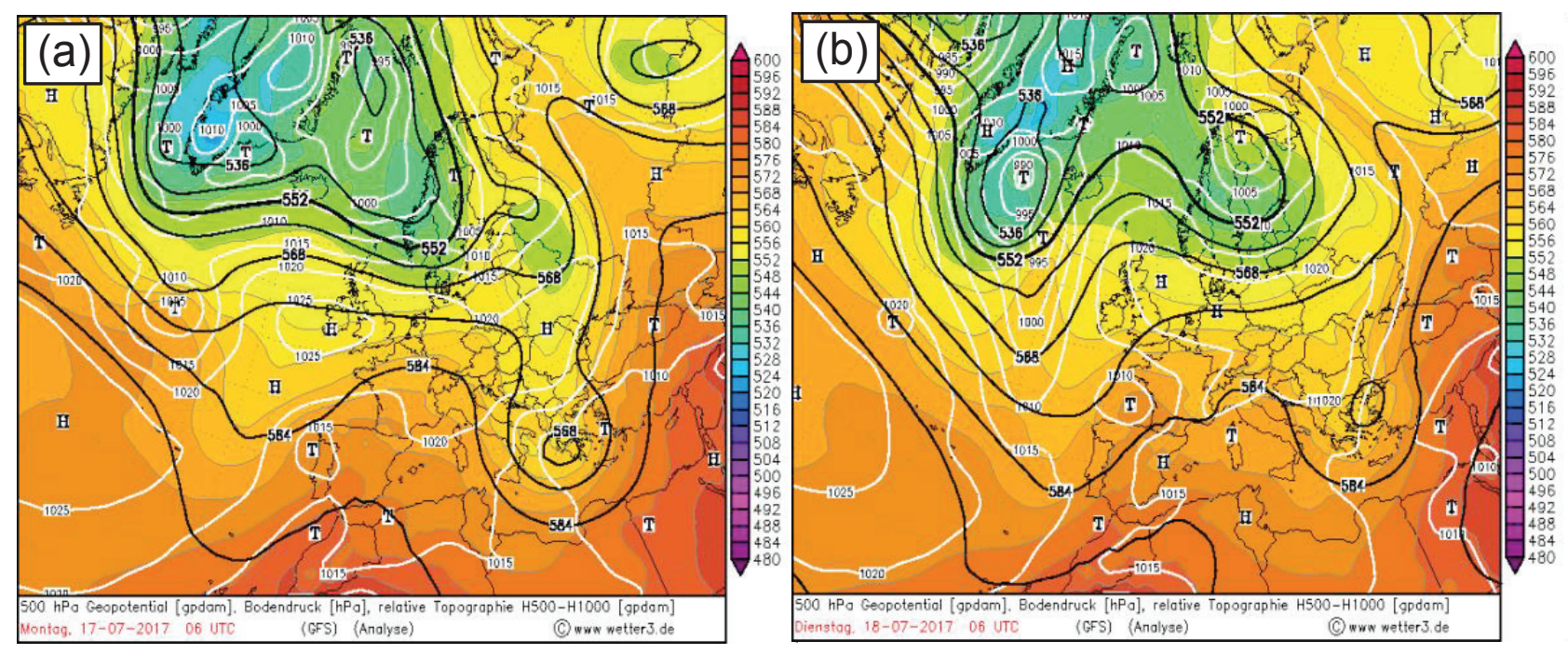

Şekil 3. Yer ve yukarı seviye haritalarının (a) 17 Temmuz 2017 06:00 UTC ve (b) 18 Temmuz 2017 06:00 UTC harita analizler 

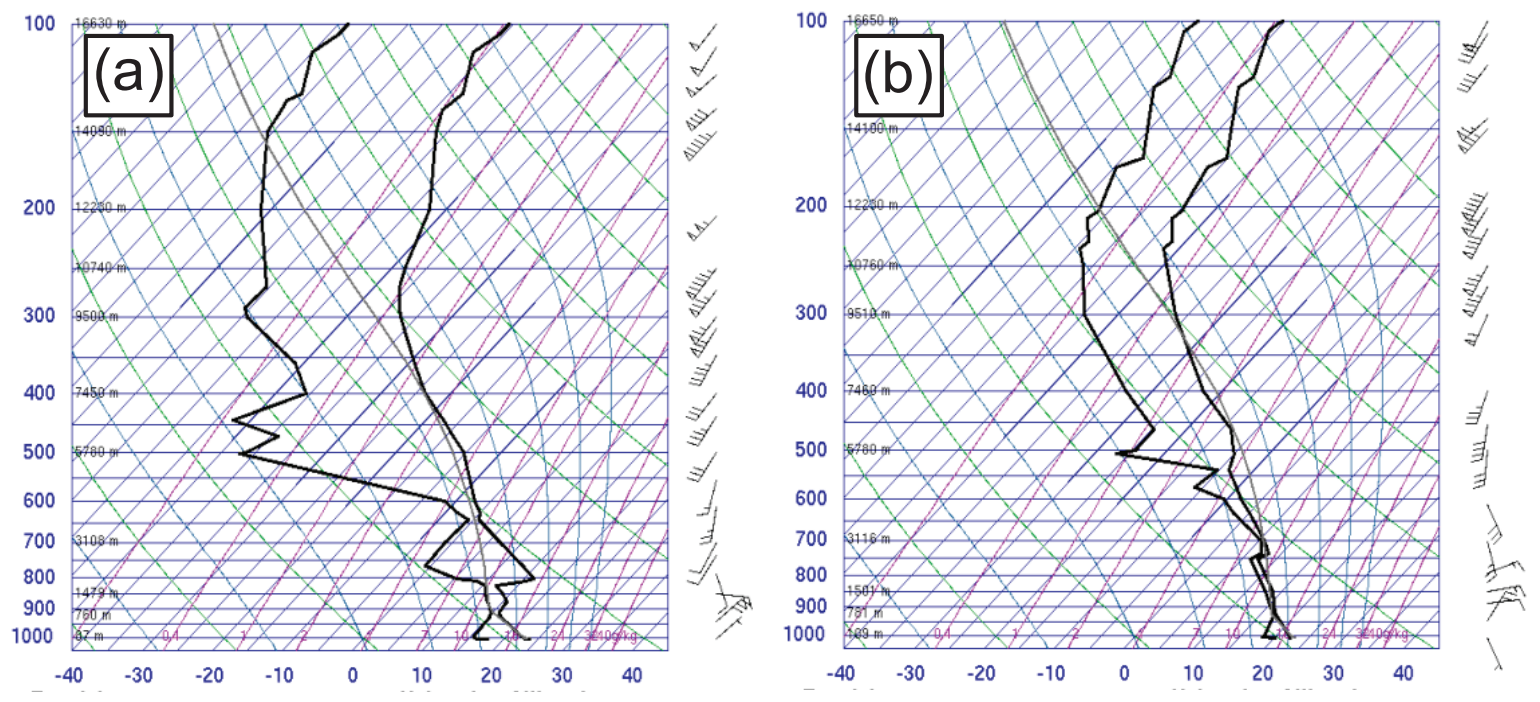

Şekil 4. SkewT-logP diyagramının (a) 17 Temmuz 2017 00:00 UTC ve (b) 18 Temmuz 2017 00:00 UTC analiz ürünleri

\subsection{SkewT-logP Diyagramı}

Konvektif oluşumların meydana gelmesinde yatay hareketin yanında dikine gelişen hareketler de oldukça önemlidir. Yukarı ve aşağı yönlü bu hareketleri inceleyebilmek amacıyla günde 2 defa 00:00 UTC' de gözlemler yapılmaktadır. Türkiye'nin 11 merkezinde yapılmakta olan bu gözlemler tahmin ve uçuculuk açısından önemli bir yer teşkil etmektedir. İstanbul'un Kartal İlçesinde yapılmakta olan radiosonde gözlemlerini sel hadisesini inceleyebilmek açısından, 17 Temmuz 00:00 UTC ve 18 Temmuz 00:00 UTC'deki atmosferik koşullar SkewT-logP diyagramlarından yararlanılarak ortaya konulmuştur. 17 Temmuz tarihinde yer seviyesinde $23.8^{\circ} \mathrm{C}$ sıcaklık değeri ile aşağı seviyelerdeki enverziyon ve kuzeyli akışlar, Karadeniz üzerinden transfer edilen nemin yukarı seviyelere transfer edilerek soğumasını engellemiş, yaklaşık $800 \mathrm{hPa}$ seviyelerinde rüzgarın güneye dönmesi sistemin yeteri kadar doygun hale gelmesini engellemiştir (Şekil 4a). Önemli kararsızlık indekslerinden TOTL indeks değeri 46 görülmekte ve kararsızlık oluşumu için 50 eşik değerinin hemen altında gerçekleşmektedir. Kararsızlık için kullanılan bir diğer indeks olan K index değeri 27.8 olup gökgürültülü sağanak yağışların belirlenmesi amacıyla kullanılan 30 eşik değerinin hemen altındadır. Aşağı seviyelerdeki nemi, yer ile yukarı seviye sıcaklık farklılıklarını ve yukarı yönlü hareketi temsil etmesi açısından kullanılan SWEAT indeks değeri ise oraj oluşumu için kullanılan 250 değerinin altında gözükmektedir (209). Bir gün sonraki Temp diyagramını incelediğimizde yer s1caklığının $22.4 \mathrm{C}$ olduğu görülmektedir. Yer ve aşağı seviyelerde bulunan alçak ve yüksek (basınç) merkezlerinin durağan olarak konumlarını korumalarından dolayı kuzeyli rüzgarlar Karadeniz üzerinden İstanbul iline nem transferini sağlamaktadır (Şekil 4b). Sinoptik haritalardan da görüldüğü gibi Yunanistan üzerinde bulunan yukarı seviye alçak merkezin Marmara Bölgesi üzerine hareketi neticesinde, $800 \mathrm{hPa}$ seviyesinden itibaren atmosfer nem açısından doygun durumda bulunmakta ve kuvvetli güneyli dikine hareketler ile su damlacıkları buz partiküllerine doğru evrilmiştir. Karasızlık indekslerinden TOTL, K ve SWEAT değerleri 48, 36.6 ve 212 olarak kaydedilmiştir. Özellikle K indeks değeri bize kuvvetli gök gürültülü yağış oluşumu için elverişli koşulların bulunduğunu göstermektedir.

\subsection{Radar Verisi Analizi}

İstanbul üzerine yerleşmekte olan yağış banlarının dağılımı ve evrimini incelemek amacıyla İstanbul'un Çatalca İlçesi'nde bulunan $\mathrm{C}$ band radarının MAX ürünleri 03:00, 04:00, 05:00 ve 05:30 UTC zamanları için Meteoroloji Genel Müdürlüğünden temin edilmiştir. 03:00 UTC'de Marmara Denizi üzerinde aniden gelişen konvektif hücreler 55 dBZ den daha büyük değerlere ulaşarak Tekirdağ'ın güney kesimlerinde şiddetli dolu hadiselerine neden olmuştur (Şekil 5a). Bir saat sonra konvektif hücreler alanını genişleterek Tekirdağ üzerinde etkili olmaya devam etmiş ve deniz üzerinden kuvvetli nem takviyesi ile beraber yağış bantlarının güneyli akışlarla birlikte Tekirdağ İli üzerine şiddetli yağışlar bıraktığı görülmektedir (Şekil 5b). Saat 05:00 UTC'de Marmara Denizi üzerindeki konvektif hücre oluşum merkezlerinin doğu-batı ekseninde geniş bir alana yayılmış olduğu görülmektedir (Şekil 5c). Bu yağış bantlarının bir kısmının İstanbul'un Avrupa 

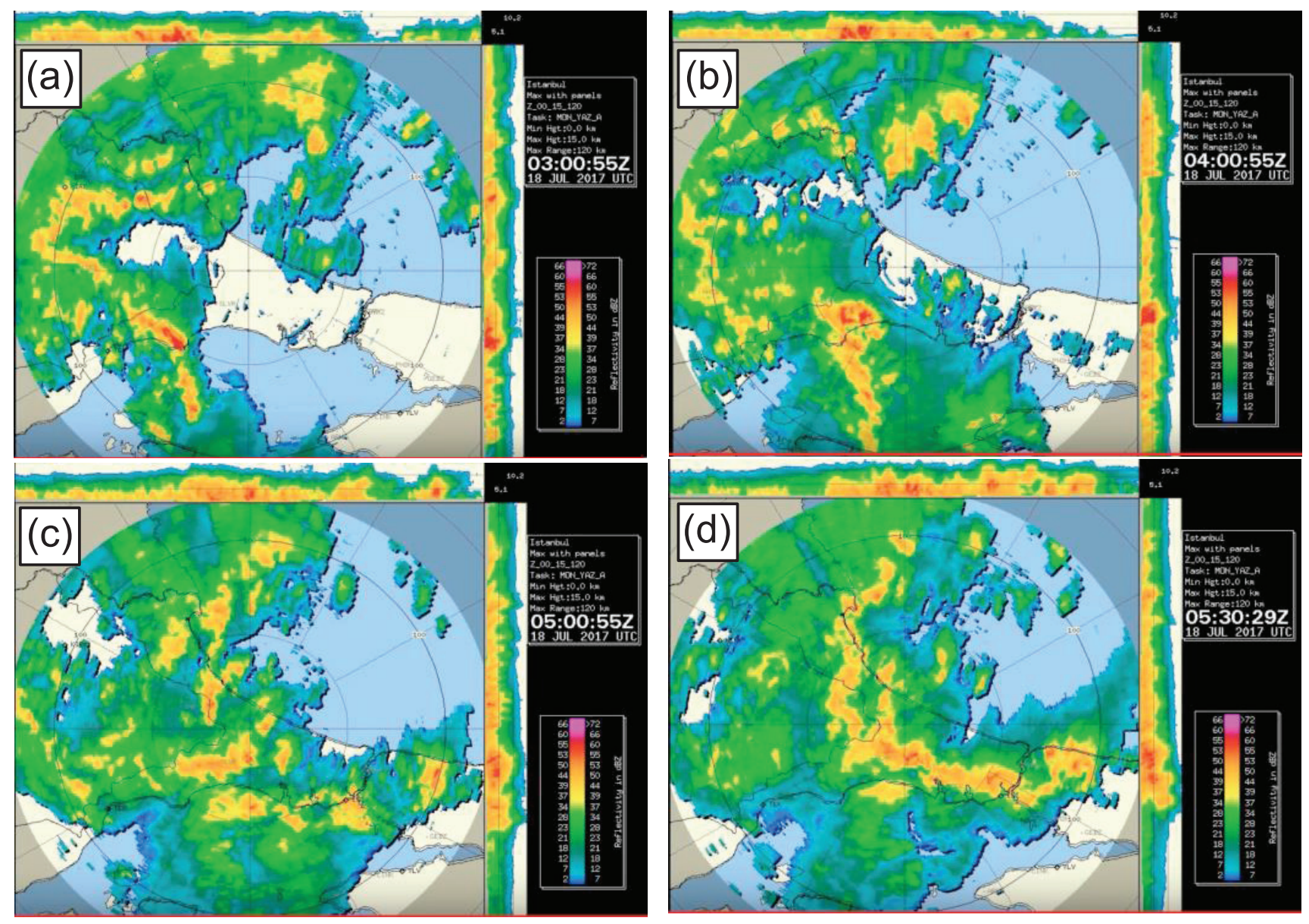

Şekil 5. İstanbul radarı MAX ürünlerinin (a) 17 Temmuz 2017 03:00 UTC, (b) 04:00 UTC, (c) 05:00 UTC ve (d) 05:30 UTC görüntüleri

Yakasında ve boğaz çevrelerinde etkin olduğu görülmektedir. Kuvvetli güneyli rüzgarlar ile beraber yarım saat içerisinde mezo ölçekli konvektif hücrelerin İstanbul İli genelinde etkin olduğu ve yoğun yağışlara neden olduğu görülmektedir. Yağışın en yoğun olduğu günün bu ilk saatlerinde (Şekil 5d), şehirleşmenin ve altyapı sorunlarının da meydana gelmesiyle ulaşımda ve sosyal yaşamda aksamalar ve ciddi ekonomik kayıplar meydana gelmiştir.

\subsection{Rüzgar Hızı ve Yağış Miktarı Değişimleri}

Orta ölçekteki konvektif sistemin geçişi esnasında rüzgar hızı ve yağış miktarındaki değişimleri incelemek amacıyla İstanbul İli üzerindeki 6 adet otomatik gözlem istasyonu verilerinden yararlanılmıştır. Bu istasyonlardan 2 si Avrupa Yakasında (Eyüp ve Büyükçekmece) ve 4'ü de Anadolu Yakasında bulunmaktadır. Genellikle kuzeyli yönlerden esmekte olan rüzgarın gece saatlerindeki şiddeti hızı 2 ila $5 \mathrm{~m} / \mathrm{sn}$ arasında değişmekte iken hücrelerin bölge üzerinde en yoğun olduğu zamanlarda şiddetinde önemli bir değişim gözükmemektedir (Şekil 6a). Öğle saatlerinden sonra bütün istasyonlarda rüzgar şiddetinin maksimum değere ulaştığı gözlenmiştir. $\mathrm{Bu}$ istasyonlardan Anadolu Yakasında bulunan Beykoz ve Kartal İstasyonları'nda en düşük değerde rüzgar hızı kayıtları mevcuttur. En kuvvetli rüzgar Büyükçekmece ve Eyüp Bölgeleri'nde $8 \mathrm{~m} / \mathrm{sn}$ değerlerine ulaşacak şekilde gözlenmiştir. Gözlenmiş olan bu değerler de göstermektedir ki, firtına oluşturacak ve sosyal yaşamı etkileyecek ölçüde kuvvetli rüzgarlar meydana gelmemiştir. Yağış açısından incelendiğinde, radar ürünleriyle de paralel olacak şekilde 05:00-06:00 UTC saatleri arasında istasyonlarda kuvvetli yağış değerleri ölçülmüştür. Bu istasyonlardan, Beykoz'da 1 saatte 44.0 mm yağış kaydedilmiş ve bunu $29.6 \mathrm{~mm}$ ile Eyüp İlçesi takip etmektedir. Şekil 6b' den de görüleceği üzere konvektif hücreler 1 saatlik periyotta kuvvetli yağışlar meydana getirmiştir. Bunun sonucu şehirleşmenin de etkisiyle altyapı sorunları meydana gelmiştir. 

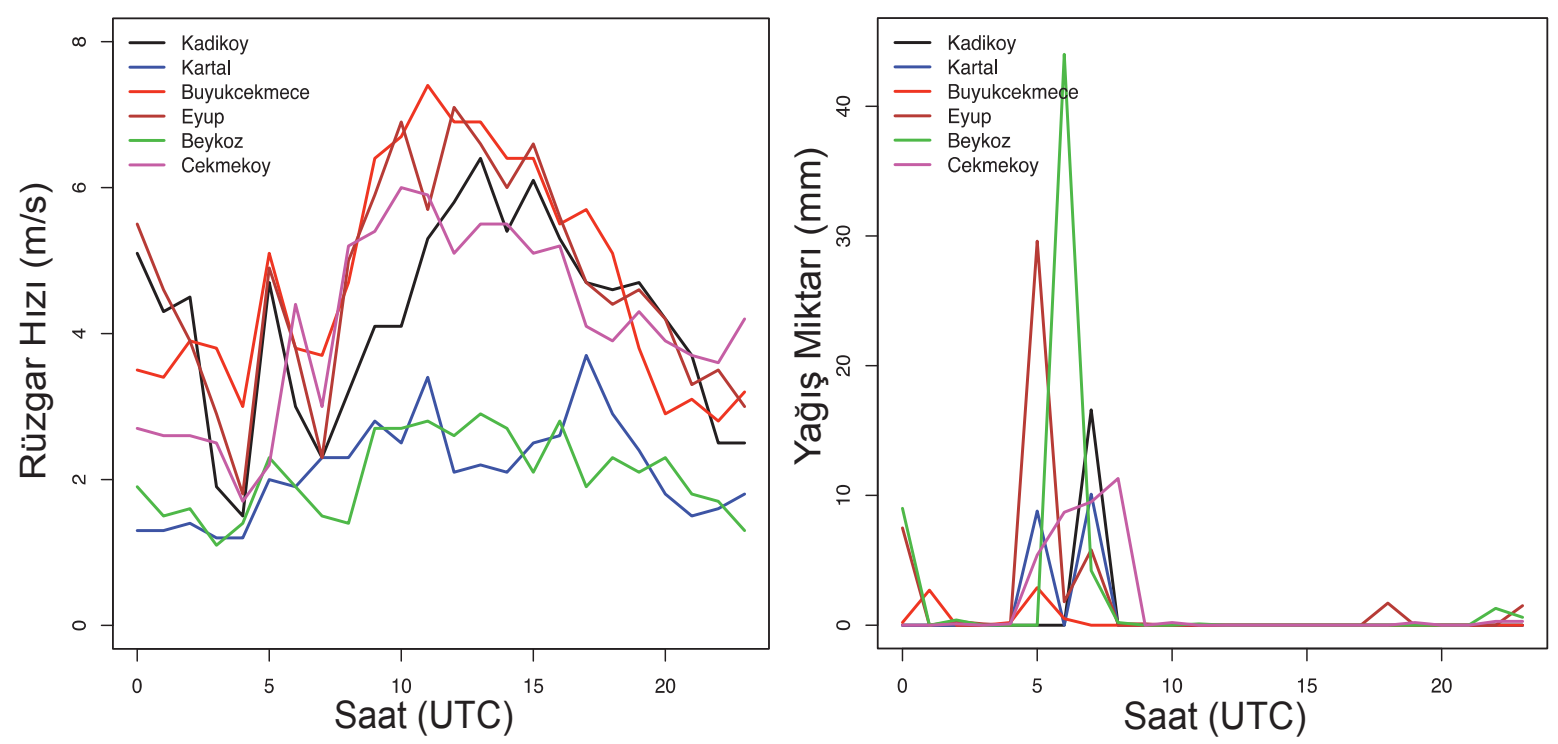

Şekil 6. İstanbul İli üzerindeki 6 adet otomatik meteoroloji istasyonunun 18 Temmuz 2017 tarihine ait saatlik (a) rüzgar şiddeti ve (b) yağış miktarı değişimleri

\section{DEĞERLENDİRME}

18 Temmuz 2017 tarihinde sabah saatlerinde İstanbul'da meydana gelen sel hadisesi ekonomik ve sosyal hayatı olumsuz yönde etkilemiştir. İstanbul Meteoroloji Bölge Müdürlüğünden elde edilen FEVK kayıtlarına göre il genelinde şiddetli yağış ile beraber yıldırım ve şimşek hadiseleri gözlenmiş, yıldırım düşmesi sonucunda 15 yangın olayına büyümeden müdahale edilmiştir. Sağanak yağmurlar neticesinde meydanlar, yollar, sokaklar, metro hatları sular altında kalmış ve ulaşımda aksamalar meydana gelmiştir. Şiddetli ve ani gelişen yağışın neticesinde meydana gelen sel hadisesinin meteorolojik değerlendirmesi yapıldığında, Azor Yüksek Basınç merkezi ile İzlanda Alçak Basınç Merkezi arasında kalan bölge üzerine kuvvetli kuzeyli rüzgarlar ile birlikte Karadeniz üzerinden nem transfer edilmiştir. Bunun yanında yukarı seviye alçak merkezinin Marmara Bölgesi üzerinde konumlanması güneyli rüzgarlar ile Ege ve Marmara Denizleri'nden nem taşınmasına imkan sağlamış, İstanbul İli’nde atmosferin aşağı ve yukarı seviyelerinde doygun atmosferik koşullar meydana getirmiştir. Bununla beraber, yer ve yukarı seviyeler arasındaki sicaklık farkı kararsızlık koşullarını artırmış ve özellikle sabah saatlerinde orta ölçekli konvektif sistemlerin meydana gelmesine neden olmuştur. Konvektif sistemler sonucunda kısa süreli ve şiddetli yağışlar İstanbul İli'nin çeşitli ilçelerinde daha etkili olmuş ekonomik ve sosyal hayatı olumsuz yönde etkilemiştir.

\section{KAYNAKLAR}

[1] Milelli, M., Llasat, M. C., \& Ducrocq, V. (2000). The cases of June 2000, November 2002 and September 2002 as examples of Mediterranean floods. Nat. Hazards Earth Syst. Sci., 6, 271-284.

[2] Kömüsçü, A. Ü., Erkan, A., \& Çelik, S. (1998). Analysis of meteorolog - ical and terrain features leading to the Izmir Flash Flood, 3-4 November 1995. Nat. Hazards, 18, 1-25.

[3] Kotroni, V., Lagouvardos, E., Defer, S., Dietrich, F., Porcu, C., Medaglia, C. M., \& Demirtas, M. (2006). The Antalya 5 Decem - ber 2002 storm: observations and model analysis. J. Appl. Meteorol. Clim., 45, 576-590.

[4] Kömüsçü, A. Ü. \& Çelik, S. (2013). Analysis of the Marmara flood in Turkey, 7-10 September 2009: an assessment from hydrometeorological perspective. Nat. Hazards, 66, 781-808.

[5] Özdemir, E. T. \& Deniz, A. (2016). Severe thunderstorm over Esenboğa International Airport in Turkey on 15 July 2013. Weather, 71(7), 157-161.

[6] Baltaci, H. (2017). Meteorological analysis of flash floods in Artvin (NE Turkey) on 24 August 2015. Nat. Hazards Earth System Sciences, 17, 1221-123 